\title{
Muellerian-Inhibiting Factor
}

National Cancer Institute

\section{Source}

National Cancer Institute. Muellerian-Inhibiting Factor. NCI Thesaurus. Code C101737.

Muellerian-inhibiting factor ( $560 \mathrm{aa}, \sim 59 \mathrm{kDa}$ ) is encoded by the human AMH gene. This protein plays a role in the development of the male reproductive system. 